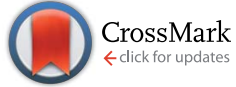

Cite this: RSC Adv., 2014, 4, 58581

Received 5th September 2014 Accepted 24th October 2014

DOI: 10.1039/c4ra09837d

www.rsc.org/advances

\title{
'Ring-expansion addition' of epoxides using applied potential: an investigation of catalysts for atmospheric pressure carbon dioxide utilization
}

\author{
Benjamin R. Buckley, ${ }^{\star}$ Anish P. Patel and K. G. Upul Wijayantha* \\ Interest in the use of $\mathrm{CO}_{2}$ as a feedstock for preparation of value-added compounds has dramatically \\ increased over the past decade. We herein investigate the insertion of atmospheric pressure carbon \\ dioxide under electrosynthetic conditions into epoxides. The initial investigations involved the use of \\ either a nickel or copper based catalyst, however, upon further optimisation and careful selection of \\ electrode materials we found that these catalysts were not required for efficient carbon dioxide insertion \\ to occur.
}

\section{Introduction}

Anticipated pressures on fossil fuel resources in the coming decades mean that raw materials for the chemical industry must be found that can reduce our reliance on fossil fuel-based feedstocks. ${ }^{1}$ Hence, the development of new production processes for chemical syntheses from renewable resources is a challenge that should be a priority for all major economies. ${ }^{2}$ Research into/application of carbon dioxide utilization (CDU) technologies has recently gained increased interest. ${ }^{3}$ CDU offers an attractive alternative to the well-established carbon dioxide storage (CCS) processes, however, scale of production means that CDU is unlikely to significantly reduce anthropogenic carbon dioxide emissions, but waste carbon dioxide under CDU protocols can be converted into useful chemicals or fuels.

Carbon dioxide is abundant, cheap and non-toxic when compared to other $\mathrm{C}_{1}$ building blocks, such as phosgene, and has been used in the manufacture of salicylic acid, urea and cyclic carbonates for 50-100 years. However, due to carbon dioxides relative inertness these processes are significantly energy demanding with reactions taking place at high temperatures and pressures. Therefore if CDU technologies are to become viable processes with reliance on very little energy input are required, hence processes at mild temperatures $\left(<100{ }^{\circ} \mathrm{C}\right)$ and atmospheric pressures should be targeted.

The chemical reduction of $\mathrm{CO}_{2}$ has received considerable interest in the last few years, both as a method for recycling $\mathrm{CO}_{2}$ in industrial waste streams and as well as a route to useful chemical products. For example, cyclic carbonates are widely used in the manufacture of products including solvents, paintstrippers, biodegradable packaging, as well as having applications in the chemical industry. Cyclic carbonates also have

Department of Chemistry, Loughborough University, Loughborough, Leicestershire, LE113TU, UK.E-mail: b.r.buckley@lboro.ac.uk potential for use in the manufacture of a new class of efficient anti-knocking agents in petrol. ${ }^{4}$

The insertion of carbon dioxide into epoxides to afford either 5 -membered ring cyclic carbonates ${ }^{5,6}$ or the corresponding polycarbonate $^{7}$ has attracted considerable attention due to the industrial application of the products arising from these reactions. For example, North and co-workers have employed bimetallic aluminium salen complexes incorporating a ammonium bromide co-catalyst such as $\mathbf{1}$ (Scheme 1) to prepare cyclic carbonates in good yield from not only highly purified carbon dioxide but also directly from a fossil fuel power station stack by use of a supported salen catalyst and flow reactor. ${ }^{8}$ These reactions take place at mild temperatures and atmospheric pressures.

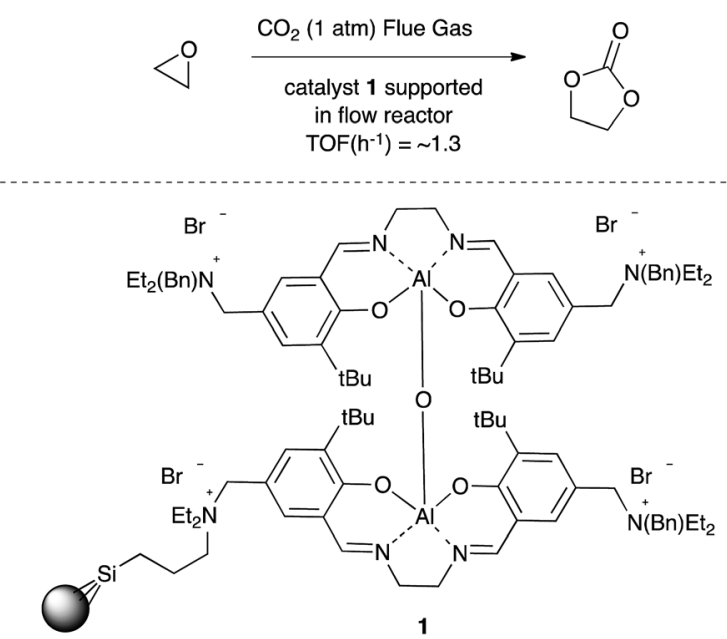

Scheme 1 One of North's catalysts for cyclic carbonate synthesis using flue gas. 
Other catalytic systems have also been successfully employed for example, Kleij and co-workers have recently reported the synthesis of 5-membered cyclic carbonates in excellent yield using either an iron, aluminium or vanadium based catalyst at $10^{-2}$ atm $\mathrm{CO}_{2} \cdot{ }^{9}$

Dunach reported in the late 1990's the nickel-catalysed electrochemical carboxylation of epoxides using a nickel(II) cyclam complex (10 mol\%) in DMF with a magnesium anode and $\mathrm{KBr}$ as electrolyte. ${ }^{\mathbf{1 0}}$ This was an attractive system for fixing $\mathrm{CO}_{2}$, when one considers that typically the reaction of epoxides with $\mathrm{CO}_{2}$ for the preparation of cyclic carbonates is generally carried out at high temperatures $\left(>100{ }^{\circ} \mathrm{C}\right)$ and elevated $\mathrm{CO}_{2}$ pressures $(>40 \mathrm{~atm})$ in the presence of a transition metal as catalyst.

\section{Results and discussion}

We were interested in developing a low energy alternative in line with our current research portfolio aimed at electrosynthesis ${ }^{11}$ coupled with semiconductor photoelectrodes to drive light assisted electrosynthetic reactions. ${ }^{12}$ We were therefore attracted to the possibility of employing an electrosynthetic system as this type of process could be designed to be cost neutral in terms of energy consumption if combined with a suitable solar powered energy source and unlike many metal catalysed processes be able to run at ambient temperature and atmospheric pressure carbon dioxide.

\section{Initial investigations of a nickel(I) catalysed system}

Our initial aims were to improve the Duñach system by running the reactions with cheaper and more accessible catalysts and in a more user-friendly reaction medium. Based on conditions reported in literature the catalysts required for electrochemical carboxylation: [Ni(bipy $\left.)_{3}\right]\left[\left(\mathrm{BF}_{4}\right)_{2}\right] 2$ and $\mathrm{Ni}\left[(\text { phen })_{3}\right]\left[\left(\mathrm{BF}_{4}\right)_{2}\right] 3$ were synthesised. ${ }^{13}$ Reactions were screened using styrene oxide 4a as substrate and run in acetonitrile in a single compartment cell containing a magnesium anode, a stainless steel cathode and $\mathrm{Bu}_{4} \mathrm{NBr}$ supporting electrolyte ( 2 eq.), at constant current: $60 \mathrm{~mA}(7 \mathrm{~h})$, with constant $\mathrm{CO}_{2}$ flow $\left(471 \mathrm{~mL} \mathrm{~min}^{-1}\right)$, in the presence of the nickel catalyst (10 mol\%) followed by heating at $50{ }^{\circ} \mathrm{C}(12 \mathrm{~h}$, Scheme 2). The reaction proceeded in the presence of the nickel catalysts 2 and 3 , forming the target cyclic carbonate $\mathbf{5 a}$, in moderate to good conversion (65 and 53\%

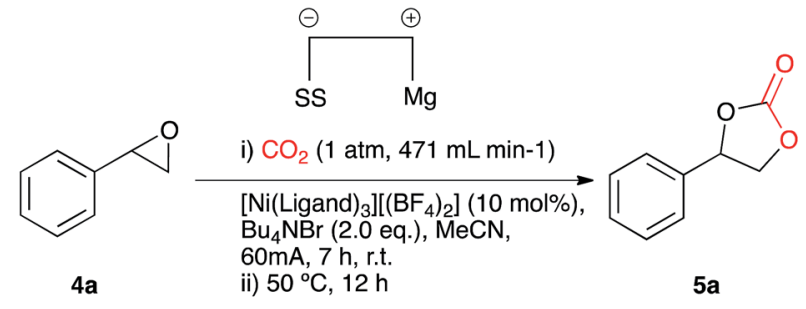

SS = stainless stee

$\left[\mathrm{Ni}(\text { bipy })_{3}\right]\left[\left(\mathrm{BF}_{4}\right)_{2}\right] 253 \%$ yield $\left[\mathrm{Ni}\left[(\text { phen })_{3}\right]\left[\left(\mathrm{BF}_{4}\right)_{2}\right] \mathbf{3} 65 \%\right.$ yield respectively). Attempts to increase the conversion using catalyst 2 were successful when the heating time was increased to $18 \mathrm{~h}$ affording the carbonate in $81 \%$ conversion by ${ }^{1} \mathrm{H}$ NMR spectroscopy (replacement of $\mathrm{Bu}_{4} \mathrm{NBr}$ with $\mathrm{Bu}_{4} \mathrm{NI}$ resulted in only $67 \%$ conversion).

In order to improve the system and move towards cheaper more accessible catalysts, $\left[\mathrm{Ni}\left(\mathrm{CH}_{3} \mathrm{CN}\right)_{4}\right]\left[\left(\mathrm{BF}_{4}\right)_{2}\right] 6$ was employed in the electrocarboxylation of styrene oxide $4 \mathrm{a}$. A test reaction (Scheme 3) involved electrolysis in acetonitrile in a single compartment cell containing a magnesium anode, a stainless steel cathode and $\mathrm{Bu}_{4} \mathrm{NBr}$ supporting electrolyte (2 eq.), at constant current: $60 \mathrm{~mA}(7 \mathrm{~h})$, with constant $\mathrm{CO}_{2}$ flow $(471 \mathrm{~mL}$ $\left.\mathrm{min}^{-1}\right)$, in the presence of the nickel catalyst $6(10 \mathrm{~mol} \%)$ followed by heating at $50{ }^{\circ} \mathrm{C}(12 \mathrm{~h})$, forming cyclic carbonate $5 \mathrm{a}$ in moderate conversion $(50 \%)$. A distinct colour change of the reaction solution on addition of the supporting electrolyte from blue to deep blue was observed during this reaction and it was thus believed that the active catalyst was the tetrahedral complex $\left[\mathrm{Ni}(\mathrm{Br})_{4}\right]$, formed from a ligand exchange reaction between bromine ions of the supporting electrolyte and the coordinated acetonitrile ligands. Furthermore stability issues of reported cross bromo/acetonitrile complexes, ${ }^{14}$ suggest that bromine ions have a stronger affinity towards $\mathrm{Ni}$ (II) in comparison to acetonitrile ligands, eliminating the possibility of a cross complex. Resulting reactions involved direct addition of the nickel reagent, $[\mathrm{Ni}(\mathrm{II})]\left[\left(\mathrm{BF}_{4}\right)_{2}\right] 7$ to the reaction solvent containing additional supporting electrolyte, $\mathrm{Bu}_{4} \mathrm{NBr}\left(\mathrm{Ni}^{2+}+4 \mathrm{Br}^{-} \rightarrow\right.$ $\left.\mathrm{Ni}(\mathrm{Br})_{4} 8\right)$ to allow in situ active catalyst formation.

The optimum catalyst loading was also investigated, this time using 1,2-epoxyoctadecane $\mathbf{4 b}$ as a test substrate. Electrocarboxylation under the test reaction conditions in the presence of nickel reagent 7 at 10, 15, 20 and 50 mol\% loading, $\mathrm{Bu}_{4} \mathrm{NBr}$ (2.4, 2.6, 2.8 and 4 equivalents) and heating for 15 hours, resulted in the corresponding cyclic carbonate $\mathbf{5 b}$, with conversion increasing with catalyst loading. Although $50 \mathrm{~mol} \%$, gave the highest conversion (90\%) in comparison to $10 \mathrm{~mol} \%$ (55\% conversion).

In order to further increase the conversion of starting material, the flow rate of $\mathrm{CO}_{2}$ entering the reaction system was studied. Electrocarboxylation of $\mathbf{4 a}$ under the test reaction conditions in the presence of $\mathrm{CO}_{2}$ at either 89,287 , or $471 \mathrm{~mL}$ $\min ^{-1}$, nickel reagent 7 (50 mol\%), $\mathrm{Bu}_{4} \mathrm{NBr}$ (4 eq.) and heating for 15 hours, produced the cyclic carbonate $\mathbf{5 a}$, with conversion generally increasing with flow rate. A flow rate of $471 \mathrm{~mL} \mathrm{~min}^{-1}$ resulted in the highest conversion (88\%).

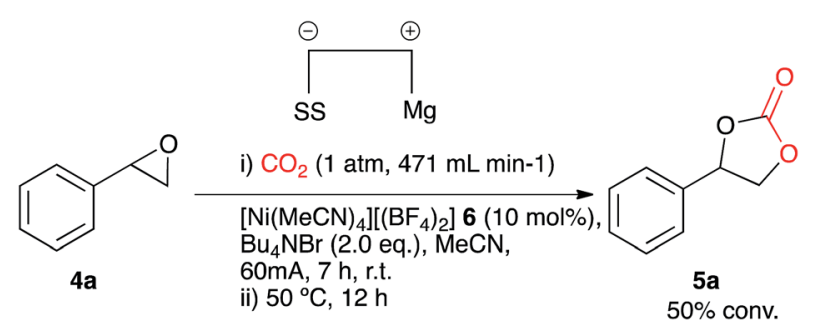

Scheme 3 Nickel catalysed conditions. 
Once the optimum reaction conditions were established: 50 mol\% loading of nickel reagent $7,15 \mathrm{~h}$ heating and $471 \mathrm{~mL}$ $\min ^{-1} \mathrm{CO}_{2}$ flow rate, and in conjunction with existing conditions: open single compartment cell, magnesium anode, stainless steel cathode, acetonitrile solvent, $\mathrm{Bu}_{4} \mathrm{NBr}$ (4 eq.) and 7 h constant current electrolysis at $60 \mathrm{~mA}$, a range of epoxide substrates were employed in order to determine the scope of the reaction conditions (Table 1). Electrocarboxylation of epoxides $\mathbf{4 a - 4 g}$ led to the formation of the target cyclic carbonates $\mathbf{5 a}-\mathbf{5 g}$ in moderate to excellent conversion (53-93\%). Substrates 4c and 4d gave moderate conversion attributed to the electron withdrawing properties of the aromatic ring substituents, although both $\mathrm{Cl}^{-}$and $\mathrm{F}^{-}$substituents are mesomerically donating $(+\mathrm{M})$ they are inductively withdrawing $(-\mathrm{I})$, thus possibly decreasing the reactivity of both substrates to nucleophiles or Lewis acid interactions.

Table 1 Electrocarboxylation using nickel based reagent $7^{a}$

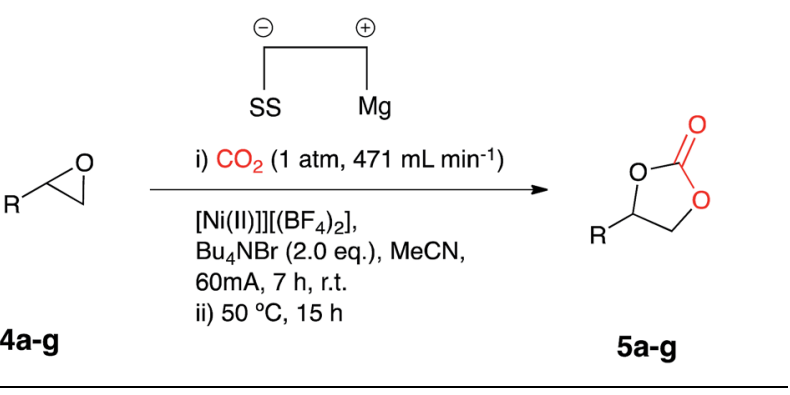

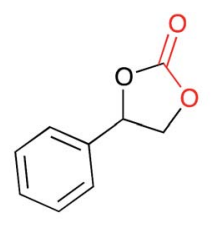

5a $90 \%$ b,c<smiles>O=C1OCC(c2ccc(F)cc2)O1</smiles>

$5 d 53 \%, c$

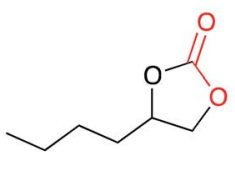

5b $80 \%$ क,c<smiles>CC1COC(=O)O1</smiles>

5e $93 \% b, c$<smiles>C=CCOCC1COC(=O)O1</smiles>

$\operatorname{5g~} 49 \%$, c<smiles>O=C1OCC(c2ccc(Cl)cc2)O1</smiles>

5 c $55 \%$ b,c<smiles>CCC1COC(=O)O1</smiles>

$5 f 90 \% b, c$
${ }^{a}$ General reaction conditions: $[\mathrm{Ni}(\mathrm{II})]\left[\left(\mathrm{BF}_{4}\right)_{2}\right](1.0 \mathrm{mmol})$, epoxide (2.0 $\mathrm{mmol})$, stainless steel cathode, magnesium anode, $\mathrm{Bu}_{4} \mathrm{NBr}(8 \mathrm{mmol})$, $\mathrm{CO}_{2}, 60 \mathrm{~mA}, 25{ }^{\circ} \mathrm{C}, 7 \mathrm{~h}$, followed by: $50{ }^{\circ} \mathrm{C}, 15 \mathrm{~h} .{ }^{b}$ Conversion evaluated from the ${ }^{1} \mathrm{H}$ NMR spectrum by integration of the epoxide $v s$. cyclic carbonate signals. ${ }^{c}$ The cyclic carbonate was the only observed product by ${ }^{1} \mathrm{H}$ NMR spectroscopy.
In order to prove the requirement of $\mathrm{CO}_{2}$, constant $\mathrm{CO}_{2}$ flow, $\mathrm{Bu}_{4} \mathrm{NBr}$ addition (4 eq.) and in situ formation of nickel catalyst 7 , control experiments were carried out, involving the attempted synthesis of cyclic carbonate $\mathbf{5 b}$ from test substrate $\mathbf{4 b}$ under optimum conditions. Electrocarboxylation with a $\mathrm{CO}_{2}$ flush (1 h) prior to electrolysis and the absence of constant $\mathrm{CO}_{2}$ flow during the reaction, resulted in minimal conversion (5\%), whereas in the absence of $\mathrm{CO}_{2}$ altogether no product formation could be detected by ${ }^{1} \mathrm{H}$ NMR spectroscopy. Electrocarboxylation using lower loadings of $\mathrm{Bu}_{4} \mathrm{NBr}(1$ eq.) resulted in decreased conversion (25\%) in comparison to using 4 equivalents $(90 \%)$, and finally electrocarboxylation using nickel catalyst 8 synthesised in $\mathrm{CH}_{3} \mathrm{CN}$ or EtOH resulted in comparable conversion (85\% and $86 \%$ ) to the in situ formed complex (90\%).

\section{Investigations of a copper(I) based system}

In search of more effective catalysts for the synthesis of cyclic carbonates led to the identification of $\left[\mathrm{Cu}\left(\mathrm{CH}_{3} \mathrm{CN}\right)_{4}\right]\left[\mathrm{BF}_{4}\right]$ 9. This coordination complex is cheaper and less toxic in comparison to the analogous nickel species. Electrocarboxylation of the test substrate $\mathbf{4 a}$ in acetonitrile in a single compartment cell containing a magnesium anode, stainless steel cathode and $\mathrm{Bu}_{4} \mathrm{NBr}$ supporting electrolyte (2.4 eq.), at constant current: $60 \mathrm{~mA}(7 \mathrm{~h})$ with constant $\mathrm{CO}_{2}$ flow $\left(471 \mathrm{~mL} \mathrm{~min}^{-1}\right)$ in the presence of copper catalyst 9 (10 mol\%) followed by heating $(12 \mathrm{~h})$ resulted in cyclic carbonate 5 a with good conversion (75\%, Scheme 4$)$. It appeared, however, that the above mentioned catalyst was not the active catalyst due to a distinct colour change of the reaction solution on addition of the supporting electrolyte from colourless to purple. Based on previously reported systems it was thought that the active catalyst could be the tetrahedral complex $\left[\mathrm{Cu}(\mathrm{Br})_{4}\right] \mathbf{1 0 .}^{15}$

The reactions employing both nickel and copper based catalysts/reagents employed the use of an open reaction vessel during the electrocarboxylation process, thus an extremely high $\mathrm{CO}_{2}$ flow rate was required in order to achieve a higher conversion of the epoxide starting material to the cyclic carbonate product. In an effort to reduce the $\mathrm{CO}_{2}$ flow rate, the experimental set-up was altered to a pseudo-sealed reaction system, where $\mathrm{CO}_{2}$ had a single inlet and outlet point, allowing the measurement and potential recovery of $\mathrm{CO}_{2}$ leaving the system. Electrocarboxylation of $\mathbf{4 a}$ using the conditions described above, using a pseudo-sealed reaction vessel and a decreased $\mathrm{CO}_{2}$ flow rate of $132 \mathrm{~mL} \min ^{-1}$, formed the

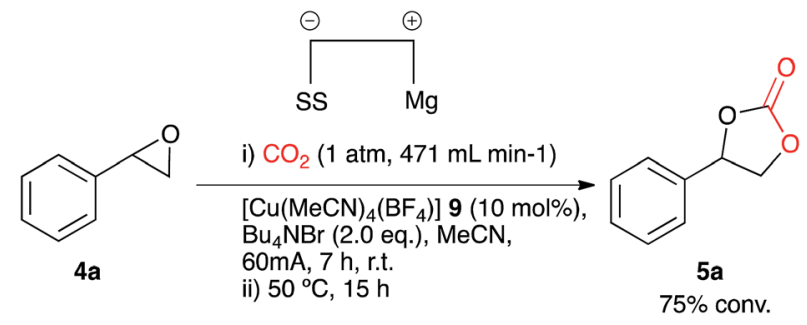

Scheme 4 Copper(I) catalysed electrocarboxylation of styrene oxide. 
corresponding cyclic carbonate $\mathbf{5 a}$ in a similar conversion (76\%) to the open reaction system ( $75 \%$, flow rate: $\left.471 \mathrm{~mL} \mathrm{~min}^{-1}\right)$.

The optimum catalyst loading for this process was investigated and electrocarboxylation of $\mathbf{4 a}$ under the initially employed conditions in a pseudo sealed reaction vessel, in the presence of copper catalyst 9 at $2.5,5$ and $10 \mathrm{~mol} \%, \mathrm{Bu}_{4} \mathrm{NBr}(2.1$, 2.2 and 2.4 eq.) and a $\mathrm{CO}_{2}$ flow rate of $132 \mathrm{~mL} \mathrm{~min}^{-1}$, resulted in the formation of the cyclic carbonate $\mathbf{5 a}$, with conversion decreasing with catalyst loading. Unusually the lowest catalyst loading of $2.5 \mathrm{~mol} \%$ resulted in a slightly higher conversion (85\%), in comparison to $5 \mathrm{~mol} \%$ (81\%) and $10 \mathrm{~mol} \%$ (78\%).

Once the optimum reaction conditions were established: pseudo-sealed single compartment cell, $2.5 \mathrm{~mol} \%$ loading of copper catalyst 9, $132 \mathrm{~mL} \min ^{-1} \mathrm{CO}_{2}$ flow rate, and in conjunction with the existing conditions: magnesium anode, stainless steel cathode, acetonitrile solvent, $\mathrm{Bu}_{4} \mathrm{NBr}$ (2.1 eq.), $7 \mathrm{~h}$ constant current electrolysis at $60 \mathrm{~mA}$ and heating for $12 \mathrm{~h}$, a range of epoxide substrates were employed in order to determine the scope of the reaction conditions (Table 2). Electrocarboxylation of epoxides $\mathbf{4 a - 4} \mathbf{g}$ led to the formation of the target cyclic carbonates $\mathbf{5 a - 5 g}$ in good to excellent conversion (60-97\%). Substrates $\mathbf{4 c}$ and $\mathbf{4 d}$ gave moderate conversion for similar reasons as mentioned for the nickel based system. Furthermore post-reaction precipitation of the supporting electrolyte resulted in good recovery of $\mathrm{Bu}_{4} \mathrm{NBr}(\sim 65 \%)$.

In order to prove in situ formation of copper catalyst 10, the requirement for a catalyst and $\mathrm{Bu}_{4} \mathrm{NBr}$ addition, control experiments were carried out, involving the attempted synthesis of cyclic carbonate 5a from test substrate $\mathbf{4 a}$ under optimum conditions. Electrocarboxylation using copper catalyst $\left[\mathrm{Cu}(\mathrm{Br})_{4}\right]$ 10 synthesised in $\mathrm{CH}_{3} \mathrm{CN}$ or EtOH resulted in comparable conversion (81\% and 83\%), to the in situ formed complex (90\%).

Electrocarboxylation using less $\mathrm{Bu}_{4} \mathrm{NBr}$ (0.1 eq.) and $\mathrm{Bu}_{4} \mathrm{NPF}_{6}$ (0.1 eq.), resulted in decreased conversion (15\%) in comparison to $\mathrm{Bu}_{4} \mathrm{NBr}$ (2.1 eq.) (90\%). A repeat of this reaction in the absence of catalyst, also resulted in conversion of starting material (16\%), although the conversion obtained was low, the result suggested the possibility of catalyst free electrocarboxylation in the presence of higher $\mathrm{Bu}_{4} \mathrm{NBr}$ loading and $\mathrm{CO}_{2}$ flow rates. $\mathrm{Bu}_{4} \mathrm{NPF}_{6}$ supporting electrolyte was selected in order to maintain a constant current during the reaction furthermore the $\mathrm{PF}_{6}{ }^{-}$counter-ions are labile and therefore noncoordinating. Finally electrocarboxylation in the absence of current between electrodes, resulted in no product formation.

\section{Investigations of a catalyst free system}

After conducting control experiments without the addition of a metal catalyst it was observed that some conversion to cyclic carbonate occurs $(16 \%)$. This was particularly interesting as it opened up the possibility of direct $\mathrm{CO}_{2}$ insertion without the requirement for an additional catalyst. In order to attempt to optimise the catalyst free system an initial test reaction was carried out using styrene oxide $\mathbf{4 a}$ and the optimised conditions used for $\mathrm{Cu}(\mathrm{I})$ catalysis, but with an increased $\mathrm{CO}_{2}$ flow rate and the absence of a catalyst. Electrocarboxylation in acetonitrile in a single compartment cell containing a magnesium anode,
Table 2 Electrocarboxylation over a range of epoxide substrates ${ }^{a}$

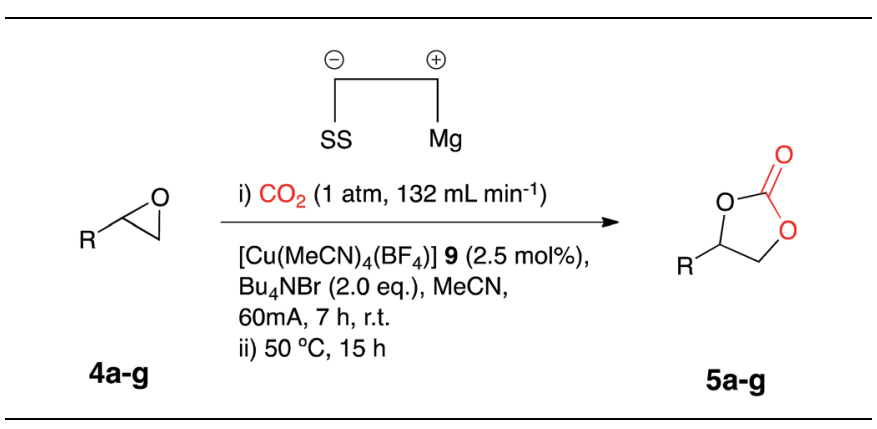<smiles>O=C1OCC(c2ccccc2)O1</smiles>

5a $85 \%, b, c$<smiles>O=C1OCC(c2ccc(F)cc2)O1</smiles>

$5 d 60 \%$ b,c

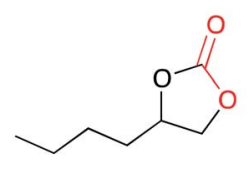

5b $90 \%$ b,c<smiles>CC1COC(=O)O1</smiles>

5e $97 \%$ b,c<smiles>C=CCOCC1COC(=O)O1</smiles>

5 g $70 \% b, c$<smiles>O=C1OCC(c2ccc(Cl)cc2)O1</smiles>

$5 \mathrm{c} 70 \%{ }^{b, c}$<smiles>CCCC1COC(=O)O1</smiles>

5f $91 \% b, c$
${ }^{a}$ General reaction conditions: $\left[\mathrm{Cu}\left(\mathrm{CH}_{3} \mathrm{CN}\right)_{4}\right]\left[\mathrm{BF}_{4}\right] \mathbf{9}(0.05 \mathrm{mmol})$ epoxide $(2.0 \mathrm{mmol})$, stainless steel cathode, magnesium anode, $\mathrm{Bu}_{4} \mathrm{NBr}(4.2$ mmol), $\mathrm{CO}_{2}, 60 \mathrm{~mA}, 25{ }^{\circ} \mathrm{C}, 7 \mathrm{~h}$, followed by: $50{ }^{\circ} \mathrm{C}, 12 \mathrm{~h} .{ }^{b}$ Conversion evaluated from the ${ }^{1} \mathrm{H}$ NMR spectrum by integration of the epoxide $v s$. cyclic carbonate signals. ${ }^{c}$ The cyclic carbonate was the only observed product by ${ }^{1} \mathrm{H}$ NMR spectroscopy.

stainless steel cathode and $\mathrm{Bu}_{4} \mathrm{NBr}(2$ eq.), at constant current: $60 \mathrm{~mA}(7 \mathrm{~h})$ with constant $\mathrm{CO}_{2}$ flow $\left(471 \mathrm{~mL} \mathrm{~min}^{-1}\right)$ followed by heating at $50{ }^{\circ} \mathrm{C}(12 \mathrm{~h})$ formed the target cyclic carbonate $5 \mathrm{a}$, in good conversion (75\%) (Scheme 5).

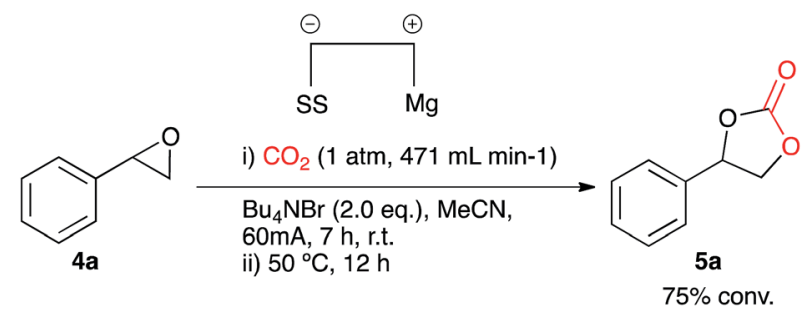

Scheme 5 Initial catalyst free conditions. 
In order to determine whether the result was anomalous or restricted to aryl epoxides, a range of substrates were employed using the conditions described in Scheme 5 (Table 3). Electrocarboxylation of epoxides $\mathbf{4 a - 4} \mathbf{g}$ led to the formation of the target cyclic carbonates $\mathbf{5 a} \mathbf{a} \mathbf{5} \mathbf{g}$ in poor to excellent conversion (33-91\%). Again substrates 5c and 5d gave moderate conversion for similar reasons as the nickel and copper catalysed systems. In general all substrates produced lower conversions in comparison to the $\mathrm{Cu}(\mathrm{I})$ catalysed system, however, we observed that the copper catalyst 9 undergoes cathodic electroplating, thus suggesting that this system was actually a pseudo-catalyst free system, with electroplated copper appearing to enhance the conversion of the epoxide starting materials in comparison to the nickel catalysed systems. Furthermore as the results for the catalyst loading study for copper catalyst 9 were very similar, it is believed that once a layer of copper has been deposited on the cathode further plating has little effect on the reaction.

Table 3 Electrocarboxylation over a range of epoxide substrates ${ }^{a}$

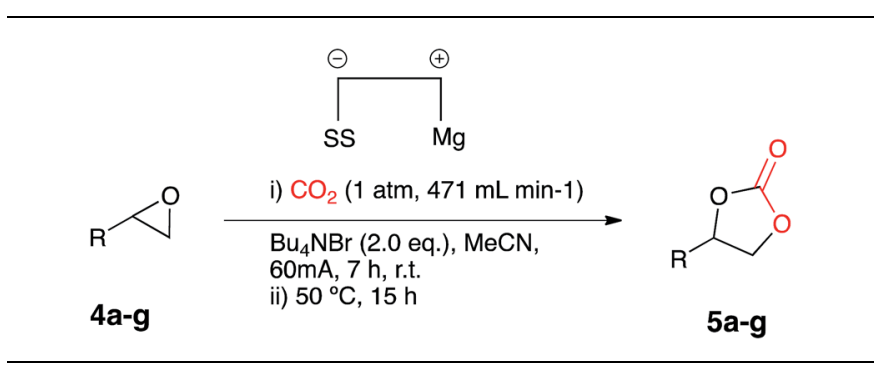

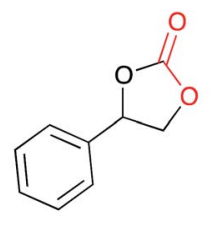

5a $75 \%$ b,c<smiles>O=C1OCC(c2ccc(F)cc2)O1</smiles>

$5 \mathbf{d} 33 \% b, c$

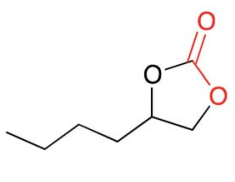

5b $79 \%$ ${ }^{b, c}$

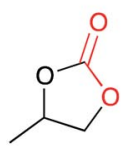

5e $85 \%$,,$c$<smiles>C=CCOCC1COC(=O)O1</smiles>

$\operatorname{sg~} 91 \%$ b,c

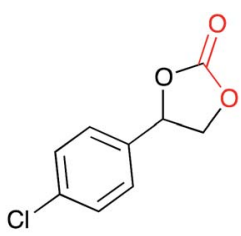

5 c $34 \%$ b,c

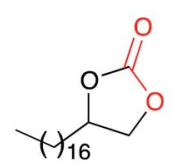

5f $56 \% b, c$

\footnotetext{
${ }^{a}$ General reaction conditions: epoxide $(2.0 \mathrm{mmol})$, stainless steel cathode, magnesium anode, $\mathrm{Bu}_{4} \mathrm{NBr}(4.0 \mathrm{mmol}), \mathrm{CO}_{2}, 60 \mathrm{~mA}, 25^{\circ} \mathrm{C}, 7$ $\mathrm{h}$, followed by: $50{ }^{\circ} \mathrm{C}, 12 \mathrm{~h} .{ }^{b}$ Conversion evaluated from the ${ }^{1} \mathrm{H}$ NMR spectrum by integration of the epoxide vs. cyclic carbonate signal. ${ }^{c}$ The cyclic carbonate was the only observed product by ${ }^{1} \mathrm{H}$ NMR spectroscopy.
}

The observed conversion of a range epoxide starting materials in the absence of a catalyst and in the presence of a magnesium anode and stainless steel cathode, suggested that the electrochemical system had the potential to be effective under catalyst free conditions. The proficiency of the process, however, was decreased because of the high $\mathrm{CO}_{2}$ flow rate being used, thus the need for a reduction in $\mathrm{CO}_{2}$ waste was investigated. A test reaction involved flushing a single compartment cell containing a magnesium anode, stainless steel, $\mathrm{Bu}_{4} \mathrm{NBr}$ supporting electrolyte ( 2 eq.) and test substrate $\mathbf{4 a}$ in acetonitrile for $1 \mathrm{~h}$ with $\mathrm{CO}_{2}$, followed by electrocarboxylation at a constant current $(60 \mathrm{~mA}, 7 \mathrm{~h})$ under a $\mathrm{CO}_{2}$ balloon with heating at $50{ }^{\circ} \mathrm{C}(12 \mathrm{~h})$, resulting in cyclic carbonate $5 \mathrm{a}$ formation with good conversion $(75 \%)$.

In order to determine the ideal electrode couple for the reaction system, a range of cathodic electrode materials were screened. Electrocarboxylation of $\mathbf{4 a}$ under the conditions described above using a copper or graphite cathode formed the corresponding cyclic carbonate 5a in excellent conversion for copper (99\%), whereas graphite produced the desired product in slightly lower conversion (85\%). It appeared that copper was a superior cathode in comparison to stainless steel (75\%) and although graphite resulted in greater conversion of starting material, slight degradation of the electrode in acetonitrile solvent was observed.

A range of anodic electrode materials were also screened. Electrocarboxylation of $\mathbf{4 a}$ under the test reaction conditions using either an aluminium, zinc, tin or copper anode formed the target cyclic carbonate $\mathbf{5 a}$ in good conversion for aluminium (75\%) and poor conversion for zinc (5\%) and tin (10\%), and in comparison, magnesium remained superior (99\%).

Identification of a magnesium anode and a copper cathode as the optimum electrode couple, was followed by full optimisation of the catalyst free conditions. Previously it was thought that two equivalents of $\mathrm{Bu}_{4} \mathrm{NBr}$ supporting electrolyte were required in order to form stoichiometric $\mathrm{MgBr}_{2}$ in situ, on the contrary, control reaction results obtained in the stainless steel cathode and magnesium anode catalyst free system suggest otherwise, therefore the $\mathrm{Bu}_{4} \mathrm{NBr}$ loading was investigated. Electrocarboxylation of $\mathbf{4 a}$ under the test reaction conditions, conversely, in the presence of a copper cathode and supporting electrolyte $\mathrm{Bu}_{4} \mathrm{NBr}$ at 50, 100 and 200 mol\% loading, produced the cyclic carbonate $\mathbf{5 a}$, with conversion increasing with electrolyte loading. Although $200 \mathrm{~mol} \%$, gave the highest conversion of starting material (99\%), $100 \mathrm{~mol} \%$ gave an almost equal conversion (98\%), thus $100 \mathrm{~mol} \%$ was selected as the optimum. The requirement of heating was also investigated with electrocarboxylation of $\mathbf{4 a}$ under the test reaction conditions in the presence of a copper cathode, $\mathrm{Bu}_{4} \mathrm{NBr}(100 \mathrm{~mol} \%)$ and the absence of a heating step, resulting in target product 5a formation in good conversion (72\%) with an increase in the electrolysis time to $10 \mathrm{~h}$ again in the absence of a heating step, resulting in only moderately higher conversion (77\%). In order to decrease the overall reaction time and energy requirement, electrocarboxylation of $\mathbf{4 a}$ was carried out under the test reaction conditions in the presence of a copper cathode and $\mathrm{Bu}_{4} \mathrm{NBr}$ (100 mol\%) with simultaneous heating, the reaction proceeded 
Table 4 Application to a range of epoxides ${ }^{a, b}$

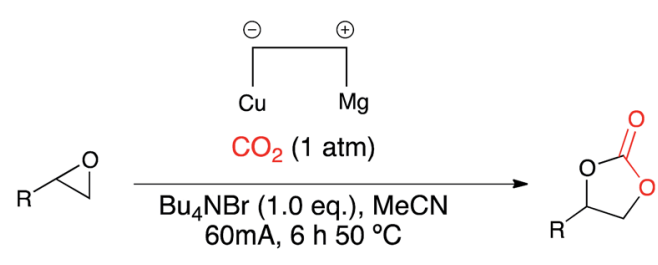

4a-o

$5 a-1$

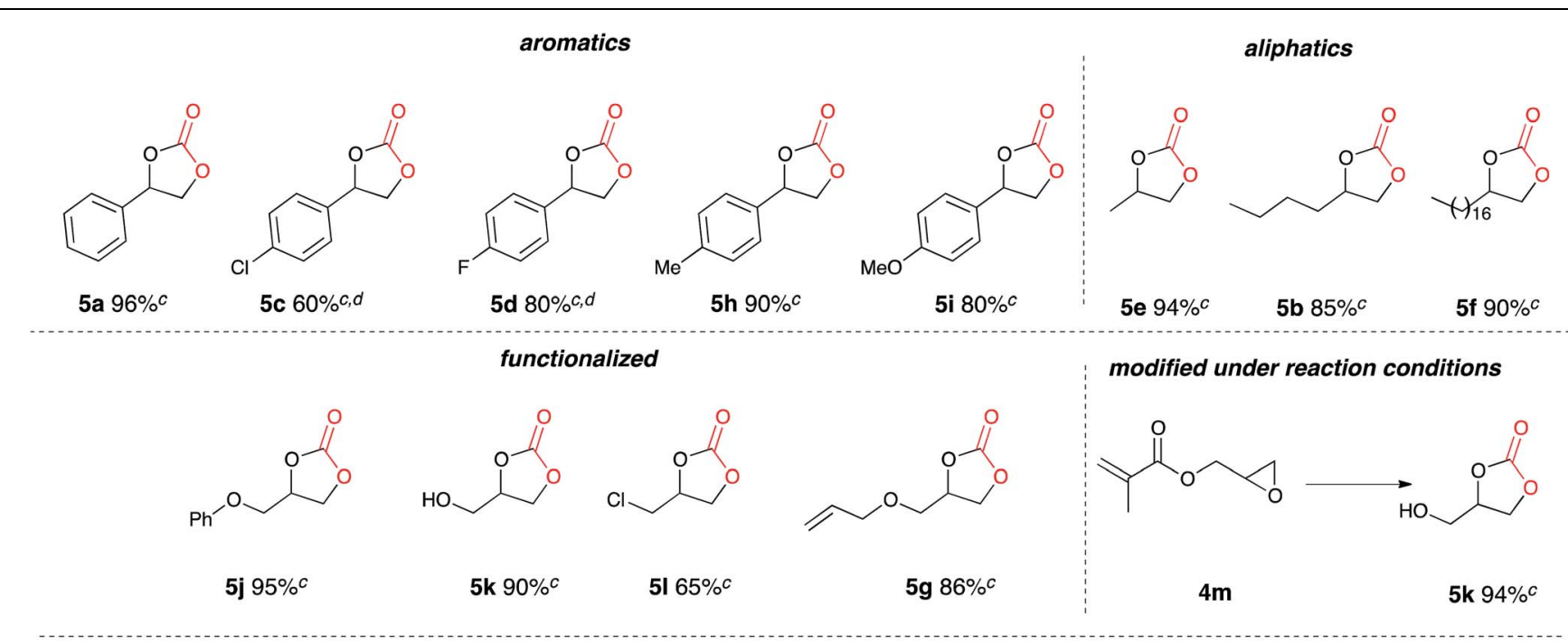

trans- and tri-substituted epoxides - no reaction
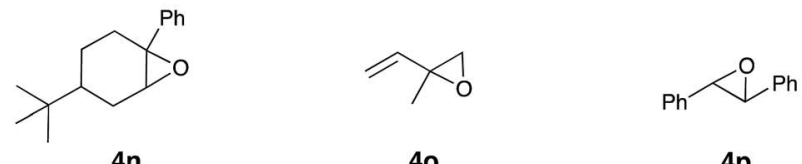

$4 n$

40

$4 p$

${ }^{a}$ General conditions: $\mathrm{CO}_{2}$, Cu cathode, $\mathrm{Mg}$ anode, $\mathrm{Bu}_{4} \mathrm{NBr}$ (2.0 equiv.), MeCN, single compartment cell, $60 \mathrm{~mA}, 6 \mathrm{~h} 50{ }^{\circ} \mathrm{C} .{ }^{b}$ On average $90-95 \%$ of the $\mathrm{Bu}_{4} \mathrm{NBr}$ is recovered after each reaction by precipitation with EtOAc and the cyclic carbonate was the only observed product by ${ }^{1} \mathrm{H}$ NMR spectroscopy. ${ }^{c}$ Isolated yield after column chromatography. ${ }^{d}$ Reaction ran for $8 \mathrm{~h}$.

to completion in $6 \mathrm{~h}$ giving excellent conversion to the corresponding cyclic carbonate $\mathbf{5 a}(98 \%)$, with a decrease in reaction time to $3 \mathrm{~h}$ leading to moderate conversion $(76 \%)$. The final optimisation reaction involved the electrocarboxylation $(6 \mathrm{~h})$ of $\mathbf{4 a}$ in air under the test reaction conditions in the presence of a copper cathode and $\mathrm{Bu}_{4} \mathrm{NBr}(100 \mathrm{~mol} \%)$ with simultaneous heating, however, this resulted in the return of starting material.

The optimum applied current was also investigated and electrocarboxylation of $\mathbf{4 a}$ under the test reaction conditions in the presence of a copper cathode, $\mathrm{Bu}_{4} \mathrm{NBr}(100 \mathrm{~mol} \%)$, and simultaneous heating at an applied current of either 20, 40, 60, 80 or $100 \mathrm{~mA}$, resulted in the formation of $\mathbf{5 a}$, with conversion increasing with applied current. The highest conversions $(100 \%)$ were observed at 60,80 and $100 \mathrm{~mA}$, whereas 20 and 40 $\mathrm{mA}$ gave poor to moderate conversion, as there was no need for additional current, $60 \mathrm{~mA}$ was maintained as the optimum applied current.
Once the optimum reaction conditions were established: sealed single compartment cell, magnesium anode, copper cathode, $100 \mathrm{~mol} \% \mathrm{Bu}_{4} \mathrm{NBr}$ loading and simultaneous heating and electrolysis at $60 \mathrm{~mA} / 50{ }^{\circ} \mathrm{C}$ for $6 \mathrm{~h}$ under a $\mathrm{CO}_{2}$ balloon, a range of epoxide substrates were employed in order to determine the scope of the reaction conditions (Table 4). Electrocarboxylation of epoxides 4a-p led to the formation of the target cyclic carbonates 4a-1 in good to excellent conversion (75-99\%) and good to excellent yield (65-96\%). Again substrates $4 \mathbf{c}$ and 4d initially gave moderate conversion attributed to the inductively electron withdrawing (-I) properties of the fluoro- and chloro- aromatic ring substituents, however an increase in the reaction time to $10 \mathrm{~h}$ enhanced both conversion and yield. In line with other studies in the area, ${ }^{7,10}$ epoxides $4 \mathbf{n}, \mathbf{4 0}$ and $\mathbf{4 p}$ did not form the target cyclic carbonate product, and as the substrates are either di- or tri-substituted the lack of reactivity is attributed to steric hinderance, thus preventing the addition of $\mathrm{Br}^{-}$to ring open the epoxide, and hence reactions resulted in 


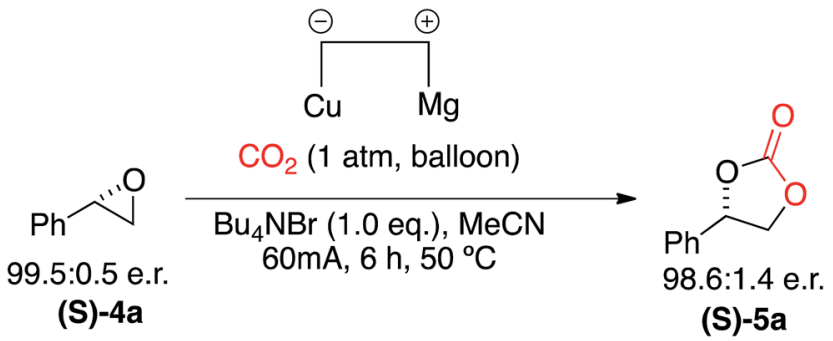

Scheme 6 Electrocarboxylation of (S)-styrene oxide (S)-4a to afford the enantiomerically pure cyclic carbonate $(S)-5 a$ with retention of configuration.

the return of starting material. Interestingly epoxide $\mathbf{4 m}$ was hydrolysed and converted into cyclic carbonate $5 \mathbf{j}$. Furthermore, post-reaction precipitation of the supporting electrolyte from these reactions resulted in good recovery of $\mathrm{Bu}_{4} \mathrm{NBr}(\sim 90 \%)$.

In order to explore the mild nature of these reaction conditions we were interested in the applicability of this system to enantiopure epoxides (Scheme 6). Application of our optimized conditions to the $\mathrm{CO}_{2}$ incorporation of $(S)$-styrene oxide $(\boldsymbol{S})$-4a afforded the cyclic carbonate $(S)$-5a in excellent yield $(97 \%)$ with retention of configuration and only a slight loss of optical purity (99.5 : 0.5 e.r. to $98.6: 1.4$ e.r.).

The scalability of the reaction for large scale synthesis was explored using propylene oxide $\mathbf{4 g}$ as the test substrate (Table 4 ), primarily due to the carboxylated product: 4-methyl-1,3dioxolan-2-one (propylene carbonate) $\mathbf{5} \mathbf{g}$ being currently synthesised in industry for use as a polar aprotic solvent. Electrocarboxylation of $\mathbf{4 g}(170 \mathrm{mmol})$ under optimised conditions resulted in the formation of the target product $\mathbf{5 g}$ in excellent conversion (100\%, 91\% yield).

A proposed mechanism of our process is highlighted in Scheme 7. Under standard heating and stirring conditions we believe the pathway shown is in operation due to the recent reports by North and coworkers ${ }^{7 e}$ and the retention of stereochemical information in the final cyclic carbonate product.

\section{Conclusions}

In conclusion we have studied the effect of several transition metal catalysts and electrode materials on the ring-expansion addition of epoxides with carbon dioxide. This process is one of a handful of emerging approaches that allow this reaction to proceed at atmospheric pressure and at ambient-mild temperatures. The yields obtained are comparable or better than those already reported in the area and our approach benefits from not employing an additional catalyst into the reaction, which in some cases can be toxic or expensive. The equipment required to perform this $\mathrm{CO}_{2}$ incorporation reaction is cheap and should be readily available in any undergraduate teaching facility i.e. copper wire, magnesium ribbon and a power supply.

\section{Experimental}

\section{Representative procedure for the ring expansion addition} reaction using nickel based catalysts (Scheme 2)

Styrene oxide $4 \mathrm{a}(0.24 \mathrm{~g}, 2.0 \mathrm{mmol})$ in acetonitrile $(50 \mathrm{~mL})$ was electrolysed at constant current: $60 \mathrm{~mA}$ for $7 \mathrm{~h}$ in a single compartment cell containing a stainless steel cathode and

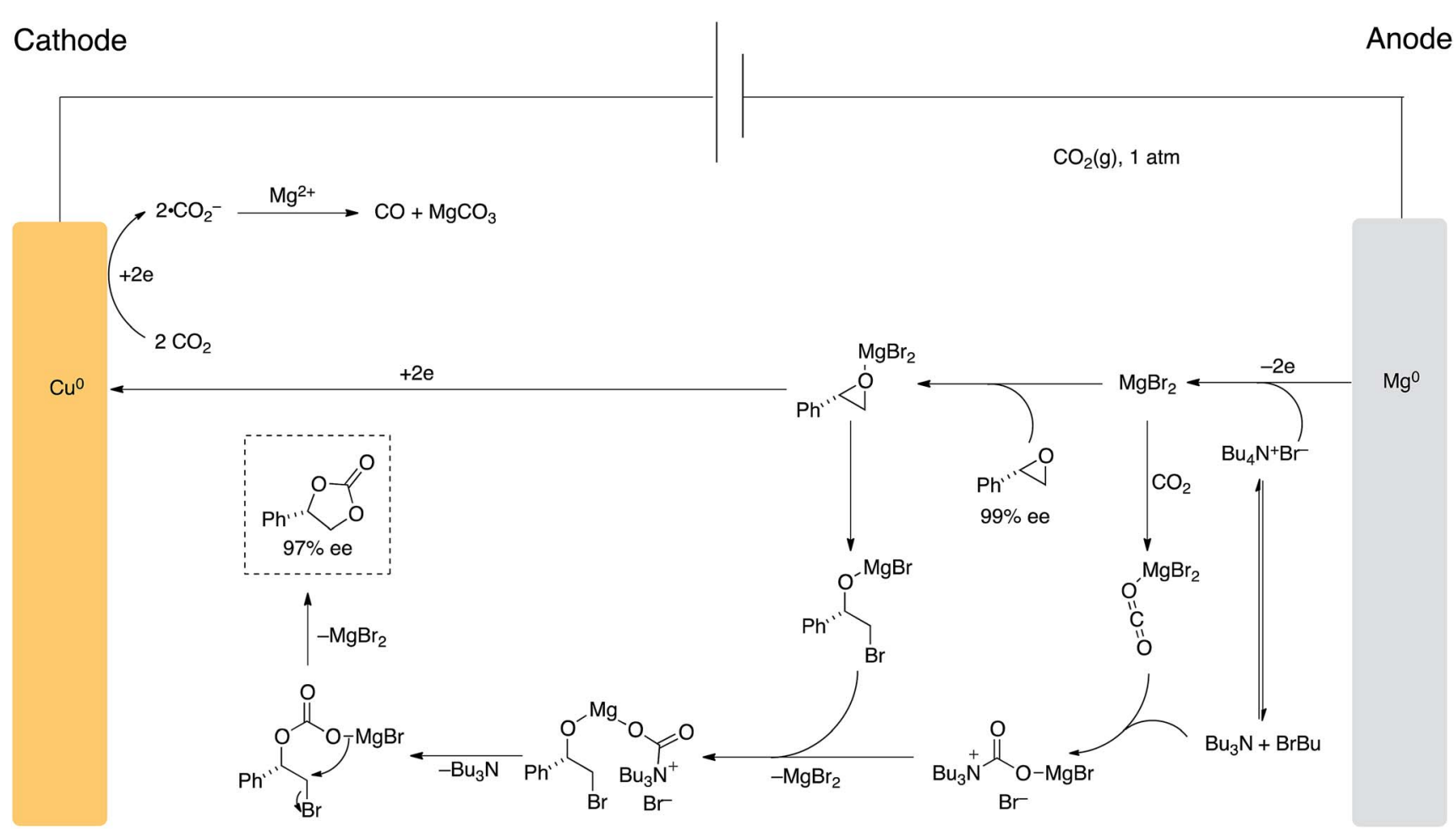

Scheme 7 Proposed mechanism for carbon dioxide 'ring-expansion addition' of epoxides using applied potential. 
magnesium anode, in the presence of catalyst (10 mol\%), supporting electrolyte: $\mathrm{Bu}_{4} \mathrm{NBr}(01.28 \mathrm{~g}, 4 \mathrm{mmol})$ and $\mathrm{CO}_{2}$, followed by heating at $50{ }^{\circ} \mathrm{C}$ for $12 \mathrm{~h}$ or $18 \mathrm{~h}$. On completion the reaction mixture was filtered and the filtrate washed with $\mathrm{HCl}(50 \mathrm{~mL} / 0.1$ M) followed by extraction using $\mathrm{Et}_{2} \mathrm{O}(3 \times 35 \mathrm{~mL})$. The combined organic extracts were washed with $\mathrm{H}_{2} \mathrm{O}(50 \mathrm{~mL})$, dried over $\mathrm{MgSO}_{4}$ and evaporated to dryness affording 4-phenyl-1,3dioxolan-2-one $\mathbf{5 b}$ as a crude amber oil. [Ni(bipy $\left.)_{3}\right]\left[\left(\mathrm{BF}_{4}\right)_{2}\right] 2$ (0.10 g, 10 mol\%) (conv.: 65\%); Ni[(phen) $\left.)_{3}\right]\left[\left(\mathrm{BF}_{4}\right)_{2}\right] 3$ (0.12 g, 10 mol\%) (conv.: 53\%).

\section{Catalyst loading study using 7 and $4 b$}

1,2-Epoxyoctadecane $4 \mathbf{b}(0.54 \mathrm{~g}, 2.0 \mathrm{mmol})$ in acetonitrile (50 $\mathrm{mL}$ ) was electrolysed at constant current: $60 \mathrm{~mA}$ with constant stirring for $7 \mathrm{~h}$ in a single compartment cell containing a stainless steel cathode and magnesium anode, in the presence of $[\mathrm{Ni}(\mathrm{II})]\left[\left(\mathrm{BF}_{4}\right)_{2}\right] 7$, supporting electrolyte: $\mathrm{Bu}_{4} \mathrm{NBr}$ and $\mathrm{CO}_{2}$, followed by heating at $50{ }^{\circ} \mathrm{C}$ for $15 \mathrm{~h}$. On completion the reaction mixture was filtered and the filtrate washed with $\mathrm{HCl}(50$ $\mathrm{mL} / 0.1 \mathrm{M})$ followed by extraction using $\mathrm{Et}_{2} \mathrm{O}(3 \times 35 \mathrm{~mL})$. The combined organic extracts were washed with $\mathrm{H}_{2} \mathrm{O}(50 \mathrm{~mL})$, dried over $\mathrm{MgSO}_{4}$ and evaporated to dryness affording 4-hexadecyl1,3-dioxolan-2-one $5 \mathbf{b}$ as a brown solid. [Ni(II)][( $\left.\left.\mathrm{BF}_{4}\right)_{2}\right](0.068 \mathrm{~g}$, $10 \mathrm{~mol} \%$ ) and $\mathrm{Bu}_{4} \mathrm{NBr}(1.55 \mathrm{~g}, 4.8 \mathrm{mmol}$ ) (conv: 53\%). $[\mathrm{Ni}(\mathrm{II})]\left[\left(\mathrm{BF}_{4}\right)_{2}\right](0.10 \mathrm{~g}, 15 \mathrm{~mol} \%)$ and $\mathrm{Bu}_{4} \mathrm{NBr}(1.68 \mathrm{~g}, 5.2 .0 \mathrm{mmol})$ (conv: $66 \%)$. [Ni(II)][(BF $\left.)_{2}\right](0.14 \mathrm{~g}, 20 \mathrm{~mol} \%)$ and $\mathrm{Bu}_{4} \mathrm{NBr}(1.81$ $\mathrm{g}, 5.6 \mathrm{mmol}$ ) (conv: 73\%). [Ni(II)][( $\left.\left(\mathrm{BF}_{4}\right)_{2}\right](0.34 \mathrm{~g}, 50 \mathrm{~mol} \%)$ and $\mathrm{Bu}_{4} \mathrm{NBr}(2.56 \mathrm{~g}, 8 \mathrm{mmol})$ (conv: 90\%).

\section{Representative procedure for the ring expansion addition reaction using $[\mathrm{Ni}(\mathrm{II})]\left[\left(\mathrm{BF}_{4}\right)_{2}\right] 7$ (Table 1)}

Styrene oxide $4 \mathrm{a}(2.0 \mathrm{mmol}, 0.24 \mathrm{~g})$ in acetonitrile $(50 \mathrm{~mL})$ was electrolysed at constant current: $60 \mathrm{~mA}$ with constant stirring for $7 \mathrm{~h}$ in a single compartment cell containing a stainless steel cathode and magnesium anode, in the presence of $[\mathrm{Ni}(\mathrm{II})]\left[\left(\mathrm{BF}_{4}\right)_{2}\right] 7$ (0.34 g, $\left.50 \mathrm{~mol} \%\right)$, supporting electrolyte: $\mathrm{Bu}_{4} \mathrm{NBr}\left(2.56 \mathrm{~g}, 8 \mathrm{mmol}\right.$ ) and $\mathrm{CO}_{2}$ (flow rate: $471 \mathrm{~mL} \mathrm{~min}{ }^{-1}$ ), followed by heating at $50{ }^{\circ} \mathrm{C}$ for $15 \mathrm{~h}$. On completion the reaction mixture was filtered and the filtrate washed with $\mathrm{HCl}$ $(50 \mathrm{~mL} / 0.1 \mathrm{M})$ followed by extraction using $\mathrm{Et}_{2} \mathrm{O}(3 \times 35 \mathrm{~mL})$. The combined organic extracts were washed with $\mathrm{H}_{2} \mathrm{O}(50 \mathrm{~mL})$, dried over $\mathrm{MgSO}_{4}$ and evaporated to dryness, followed by purification by column chromatography on silica affording 4-phenyl-1,3-dioxolan-2-one $\mathbf{5 a}$ as a colourless solid (90\% conv.).

Representative procedure for the ring expansion addition reaction using $\left[\mathrm{Cu}(\mathrm{MeCN})_{4}\left(\mathrm{BF}_{4}\right)\right] 9$ (Table 2)

Styrene oxide $4 \mathrm{a}(0.24 \mathrm{~g}, 2.0 \mathrm{mmol})$ in acetonitrile $(150 \mathrm{~mL})$ was electrolysed at constant current: $60 \mathrm{~mA}$ with constant stirring for $7 \mathrm{~h}$ in a single compartment cell containing a stainless steel cathode and magnesium anode, in the presence of $\left[\mathrm{Cu}\left(\mathrm{CH}_{3} \mathrm{CN}\right)_{4}\right]\left[\mathrm{BF}_{4}\right] \quad 9(0.018 \mathrm{~g}, 2.5 \mathrm{~mol} \%)$, supporting electrolyte: $\mathrm{Bu}_{4} \mathrm{NBr}(1.35 \mathrm{~g}, 4.2 .0 \mathrm{mmol})$ and $\mathrm{CO}_{2}$ (flow rate: $132 \mathrm{~mL} \min ^{-1}$ ), followed by heating at $50{ }^{\circ} \mathrm{C}$ for $12 \mathrm{~h}$. On completion the reaction mixture was filtered and filtrate was evaporated to dryness followed by addition of EtOAc $(50 \mathrm{~mL})$.
After $1 \mathrm{~h}$ precipitated $\mathrm{Bu}_{4} \mathrm{NBr}(0.48 \mathrm{~g}, 65 \%$ recovered) was removed by filtration and the solvent evaporated, followed by purification by column chromatography on silica affording 4-phenyl-1,3-dioxolan-2-one 5a, as a colourless solid (conv: 85\% conv.).

Representative procedure for the ring expansion addition reaction using a stainless steel anode and magnesium cathode under catalyst free conditions (Table 3)

Styrene oxide $4 \mathrm{a}(0.24 \mathrm{~g}, 2.0 \mathrm{mmol})$ in acetonitrile $(150 \mathrm{~mL})$ was electrolysed at constant current: $60 \mathrm{~mA}$ with constant stirring for $7 \mathrm{~h}$ in a single compartment cell containing a stainless steel cathode and magnesium anode, in the presence of supporting electrolyte: $\mathrm{Bu}_{4} \mathrm{NBr}\left(1.28 \mathrm{~g}, 4 \mathrm{mmol}\right.$ ) and $\mathrm{CO}_{2}$ (flow rate: $471 \mathrm{~mL}$ $\min ^{-1}$ ), followed by heating at $50{ }^{\circ} \mathrm{C}$ for $12 \mathrm{~h}$. On completion the reaction mixture was filtered and filtrate was evaporated to dryness followed by addition of EtOAc $(50 \mathrm{~mL})$. After $1 \mathrm{~h}$ precipitated $\mathrm{Bu}_{4} \mathrm{NBr}(\sim 70 \%$ recovered) was removed by filtration and the solvent evaporated, affording 4-phenyl-1,3dioxolan-2-one 5a, as a crude amber oil (conv: 75\%).

General Procedure for the ring expansion addition reaction using a copper anode and magnesium cathode under catalyst free conditions (Table 4)

Representative procedure for the synthesis of phenyl ethylene carbonate 5a: Styrene oxide $4 \mathrm{a}(0.12 \mathrm{~g}, 1.0 \mathrm{mmol})$ and $\mathrm{CO}_{2}$ (balloon) in acetonitrile $(150 \mathrm{~mL})$ were electrolysed (constant current: $60 \mathrm{~mA}$ ) for $6 \mathrm{~h}$ in a single compartment cell $(\mathrm{Mg}$ anode and copper(0) cathode) containing $\mathrm{Bu}_{4} \mathrm{NBr}(0.32 \mathrm{~g}, 1.0 \mathrm{mmol})$ as supporting electrolyte at $50{ }^{\circ} \mathrm{C}$. On completion the reaction mixture was washed with aqueous $0.1 \mathrm{M} \mathrm{HCl}(50 \mathrm{~mL})$ followed by extraction with $\mathrm{Et}_{2} \mathrm{O}(3 \times 35 \mathrm{~mL})$. The combined organic extracts were then dried over $\mathrm{MgSO}_{4}$ and evaporated under reduced pressure to afford a amber oil, which was suspended in EtOAc $(100 \mathrm{~mL})$. After $1 \mathrm{~h}$ the precipitated $\mathrm{Bu}_{4} \mathrm{NBr}(0.30 \mathrm{~g}, 95 \%)$ was removed by filtration and the solvent evaporated under reduced pressure to afford an amber oil. This crude material was purified by column chromatography on silica gel eluting with ethyl acetate:light petroleum. Colourless solid $(0.157 \mathrm{~g}, 96 \%)$.

\section{Data for the cyclic carbonates 5a-51}

4-Phenyl-1,3-dioxolan-2-one (styrene carbonate) 5a. Colourless solid; mp 49-51 ${ }^{\circ} \mathrm{C}$; $\nu_{\max }\left(\mathrm{CH}_{2} \mathrm{Cl}_{2}\right) / \mathrm{cm}^{-1} 1160(\mathrm{C}-\mathrm{O}), 1756$ $(\mathrm{C}=\mathrm{O}) ;{ }^{1} \mathrm{H}$ NMR $\left(400 \mathrm{MHz}, \mathrm{CDCl}_{3}\right) \delta: 3.45(1 \mathrm{H}, \mathrm{dd}, J=7.93, J=$ $7.93), 4.80(1 \mathrm{H}, \mathrm{dd}, J=8.49, J=8.33), 5.68(1 \mathrm{H}, \mathrm{dd}, J=7.99, J=$ 7.99), 7.35-7.45 (5H, m); ${ }^{13} \mathrm{C} \mathrm{NMR}\left(400 \mathrm{MHz} \mathrm{CDCl}_{3}\right) \delta: 71.2$, 78.00, 125.9, 129.3, 129.8, 135.8, 154.8 .

4-Butyl-1,3-dioxolan-2-one (1-hexene carbonate) 5b. Colourless oil; $\nu_{\max }\left(\mathrm{CH}_{2} \mathrm{Cl}_{2}\right) / \mathrm{cm}^{-1} 1171(\mathrm{C}-\mathrm{O}), 1770(\mathrm{C}=\mathrm{O}) ;{ }^{1} \mathrm{H}$ NMR $\left(400 \mathrm{MHz}, \mathrm{CDCl}_{3}\right) \delta: 0.93(3 \mathrm{H}, \mathrm{t}, J=7.36, J=7.38), 1.34-1.49$ $(2 \mathrm{H}, \mathrm{m}), 1.65-1.74(2 \mathrm{H}, \mathrm{m}), 1.78-1.87(2 \mathrm{H}, \mathrm{m}), 4.07$ (1H, dd, $J=$ $7.2, J=7.2), 4.53(1 \mathrm{H}, \mathrm{dd}, J=7.98, J=8.26), 4.69-4.72(1 \mathrm{H}, \mathrm{m})$; ${ }^{13} \mathrm{C} \mathrm{NMR}\left(400 \mathrm{MHz}, \mathrm{CDCl}_{3}\right) \delta: 13.8,22.8,26.5,29.7,33.6,69.4$, 155.1 . 
4-(4-Chlorophenyl)-1,3-dioxolan-2-one (4-chlorostyrene carbonate) 5c. Colourless solid; $\mathrm{mp} 67-69^{\circ} \mathrm{C} ; \nu_{\max }\left(\mathrm{CH}_{2} \mathrm{Cl}_{2}\right) / \mathrm{cm}^{-1}$ $1165(\mathrm{C}-\mathrm{O}), 1761(\mathrm{C}=\mathrm{O}) ;{ }^{1} \mathrm{H}$ NMR (400 $\left.\mathrm{MHz} \mathrm{CDCl}_{3}\right) \delta: 4.31$ $(1 \mathrm{H}, \mathrm{dd}, J=7.85, J=7.89), 4.80(1 \mathrm{H}, \mathrm{dd}, J=8.43, J=8.43), 5.66$ $(1 \mathrm{H}, \mathrm{dd}, J=7.96, J=7.96), 7.27-7.32(2 \mathrm{H}, \mathrm{m}), 7.42-7.44(2 \mathrm{H}, \mathrm{m})$; ${ }^{13} \mathrm{C} \mathrm{NMR}\left(400 \mathrm{MHz}, \mathrm{CDCl}_{3}\right) \delta: 71.0,77.2,127.3,129.5,134.3$, 135.8, 154.5 .

4-(4-Fluorophenyl)-1,3-dioxlan-2-one

(4-fluorostyrene carbonate) 5 d. Colourless solid; mp $62-64{ }^{\circ} \mathrm{C} ; \nu_{\max }\left(\mathrm{CH}_{2} \mathrm{Cl}_{2}\right) /$ $\mathrm{cm}^{-1} 1167$ (C-O), 1763 (C=O); ${ }^{1} \mathrm{H}$ NMR (400 MHz, $\mathrm{CDCl}_{3}$ ) $\delta$ : $4.33(1 \mathrm{H}, \mathrm{dd}, J=7.93, J=8.75), 4.80(1 \mathrm{H}, \mathrm{dd}, J=8.21, J=8.59)$, $5.66(1 \mathrm{H}, \mathrm{dd}, J=8.02, J=8.02), 7.11-7.17(2 \mathrm{H}, \mathrm{m}), 7.34-7.39$ $(2 \mathrm{H}, \mathrm{m}) ;{ }^{13} \mathrm{C}$ NMR $\left(400 \mathrm{MHz}, \mathrm{CDCl}_{3}\right) \delta: 71.1,76.7,77.4,116.0$, 127.4, 131.5, 154.6, 162.2, 164.6.

4-Methyl-1,3-dioxolan-2-one (propylene carbonate) 5e. Colourless oil; $\nu_{\max }\left(\mathrm{CH}_{2} \mathrm{Cl}_{2}\right) / \mathrm{cm}^{-1} 1204(\mathrm{C}-\mathrm{O}), 1779(\mathrm{C}=\mathrm{O}) ;{ }^{1} \mathrm{H}$ NMR (400 MHz, $\mathrm{CDCl}_{3}$ ) $\delta: 1.49(3 \mathrm{H}, \mathrm{d}, J=6.27), 4.04(1 \mathrm{H}, \mathrm{dd}, J=$ $7.27, J=7.27), 4.57(1 \mathrm{H}, \mathrm{dd}, J=7.71, J=7.81), 4.83-4.90(1 \mathrm{H}$, $\mathrm{m}) ;{ }^{13} \mathrm{C}$ NMR $\left(400 \mathrm{MHz}, \mathrm{CDCl}_{3}\right) \delta: 19.4,70.7,73.6,155.1$.

4-Hexadecyl-1,3-dioxolan-2-one (1-octadecene carbonate) $5 f$ Colourless solid; $\mathrm{mp} 45-47{ }^{\circ} \mathrm{C} ; \nu_{\max }(\mathrm{film}) / \mathrm{cm}^{-1} 1170$ (C-O), $1774(\mathrm{C}=\mathrm{O}) ;{ }^{1} \mathrm{H}$ NMR $\left(400 \mathrm{MHz}, \mathrm{CDCl}_{3}\right) \delta: 0.88(3 \mathrm{H}, \mathrm{t}, J=7.06, J$ $=6.97), 1.21-1.48(26 \mathrm{H}, \mathrm{m}), 1.63-1.72(2 \mathrm{H}, \mathrm{m}), 1.77-1.86(2 \mathrm{H}$, $\mathrm{m}), 1.63-1.72(2 \mathrm{H}, \mathrm{m}), 4.07(1 \mathrm{H}, \mathrm{dd}, J=7.43, J=7.37), 4.52(1 \mathrm{H}$, $\mathrm{dd}, J=8.07, J=8.15), 4.69(1 \mathrm{H}, \mathrm{m}) ;{ }^{13} \mathrm{C} \mathrm{NMR}\left(400 \mathrm{MHz}, \mathrm{CDCl}_{3}\right)$ $\delta: 14.1,22.7,24.4,29.2,29.4,29.4,29.5,29.6,29.6,29.7,29.7$, 31.9, 33.9, 69.4, 155.1.

4-(Allyloxymethyl)-1,3-dioxolan-2-one 5g. Colourless oil; $\nu_{\max }$ (film) $/ \mathrm{cm}^{-1} 1179(\mathrm{C}-\mathrm{O}), 1646(\mathrm{C}=\mathrm{C}), 1792(\mathrm{C}=\mathrm{O}) ;{ }^{1} \mathrm{H}$ NMR (400 $\left.\mathrm{MHz} \mathrm{CDCl}_{3}\right) \delta: 3.60-3.73(2 \mathrm{H}, \mathrm{m}), 4.00-4.08$ (2H, m), 4.39-4.44 (1H, m), 4.50-4.57 (1H, m), 4.81-4.87 (1H, m), 5.21-5.31 (2H, m) 5.83-5.94 (1H, m); $\left.{ }^{13} \mathrm{C} \mathrm{NMR} \mathrm{(400} \mathrm{MHz,} \mathrm{CDCl}_{3}\right) \delta: 66.3,68.9,72.5$, 75.1, 117.9, 133.7, 155.1.

4-(4-Methylphenyl)-1,3-dioxolan-2-one (4-methylstyrene carbonate) 5h. Colourless solid; $\mathrm{mp} 40-41{ }^{\circ} \mathrm{C} ; \nu_{\max }\left(\mathrm{CH}_{2} \mathrm{Cl}_{2}\right) /$ $\mathrm{cm}^{-1} 1165(\mathrm{C}-\mathrm{O}), 1460(\mathrm{C}=\mathrm{C}), 1737(\mathrm{C}=\mathrm{O}) ; \delta_{\mathrm{H}}(400 \mathrm{MHz}$, $\left.\mathrm{CDCl}_{3}, \mathrm{Me}_{4} \mathrm{Si}\right) 2.35$ (3H, s), 4.34 (1H, dd, $J$ 8.18), 4.77 (1H, dd, $J$ 8.56), 5.64 (1H, dd, $J$ 8.06), 7.23-7.28 (4H, m); $\delta_{\mathrm{C}}(100 \mathrm{MHz}$, $\left.\mathrm{CDCl}_{3}, \mathrm{Me}_{4} \mathrm{Si}\right)$ 21.3, 71.2, 76.9, 78.1, 126.0, 129.9, 132.7, 139.9.

4-(4-Methoxyphenyl)-1,3-dioxolan-2-one (4-methoxystyrene carbonate) 5i. Colourless solid; $\mathrm{mp} 42-44{ }^{\circ} \mathrm{C} ; \nu_{\max }\left(\mathrm{CH}_{2} \mathrm{Cl}_{2}\right) /$ $\mathrm{cm}^{-1} 1072$ (C-O), $1812(\mathrm{C}=\mathrm{O}) ;{ }^{1} \mathrm{H}$ NMR (400 MHz, $\left.\mathrm{CDCl}_{3}\right) \delta$ : $3.83(3 \mathrm{H}, \mathrm{s}), 4.35$ (1H, dd $J=8.14, J=8.17), 4.75(1 \mathrm{H}, \mathrm{dd}, J=$ $8.17, J=8.17), 5.62(1 \mathrm{H}, \mathrm{dd}, J=8.05, J=8.11), 6.94-6.97(2 \mathrm{H}$, $\mathrm{dd}, \mathrm{m}), 7.26-7.32$ (2H, m). ${ }^{13} \mathrm{C}$ NMR (400 MHz, $\left.\mathrm{CDCl}_{3}\right) \delta: 55.4$, 71.1, 78.1, 114.6, 127.6, 154.9, 160.8 .

4-Phenoxymethyl-[1,3]-dioxolan-2-one 5j. Colourless solid; $\operatorname{mp} 103-105{ }^{\circ} \mathrm{C} ; \nu_{\max }\left(\mathrm{CH}_{2} \mathrm{Cl}_{2}\right) / \mathrm{cm}^{-1} 1166(\mathrm{C}-\mathrm{O}), 1783(\mathrm{C}=\mathrm{O}) ;{ }^{1} \mathrm{H}$ NMR (400 MHz, $\left.\mathrm{CDCl}_{3}\right) \delta:$ 4.14-4.26 (2H, m), 4.52-4.64 (2H, m), 5.00-5.06 (1H, m), 6.90-6.92 (2H, m), 7.00-7.04 (1H, m), 7.26$7.33(2 \mathrm{H}, \mathrm{m}) ;{ }^{13} \mathrm{C} \mathrm{NMR}\left(400 \mathrm{MHz}, \mathrm{CDCl}_{3}\right) \delta: 66.3,66.9,74.1$, 114.6, 122.0, 129.7, 154.6, 157.7.

4-(Hydroxymethyl)-1,3-dioxolan-2-one 5k. Colourless oil; $\nu_{\max }\left(\mathrm{CH}_{2} \mathrm{Cl}_{2}\right) / \mathrm{cm}^{-1} 1180(\mathrm{C}-\mathrm{O}), 1782(\mathrm{C}=\mathrm{O}), 3411(\mathrm{O}-\mathrm{H}) ;{ }^{1} \mathrm{H}$ NMR (400 MHz, $\left.\mathrm{CDCl}_{3}\right) \delta: 2.89(1 \mathrm{H}, \mathrm{s}), 3.71(1 \mathrm{H}, \mathrm{dd}, J=3.49, J=$ 3.41), 3.99 (1H, dd, $J=2.97, J=2.97)$, 4.50-4.56 (2H, m), 4.97-
$4.84(1 \mathrm{H}, \mathrm{m}) ;{ }^{13} \mathrm{C}$ NMR $\left(400 \mathrm{MHz}, \mathrm{CDCl}_{3}\right) \delta: 61.7,65.8,76.7$, 155.5 .

4-(Chloromethyl)-1,3-dioxolan-2-one 5l. Colourless oil; $\nu_{\max }$ $\left(\mathrm{CH}_{2} \mathrm{Cl}_{2}\right) / \mathrm{cm}^{-1} 1078$ (C-Cl), 1193 (C-O), 1643 (C=O); ${ }^{1} \mathrm{H}$ NMR $\left(400 \mathrm{MHz}, \mathrm{CDCl}_{3}\right) \delta: 3.72-3.81(2 \mathrm{H}, \mathrm{m}), 4.42(1 \mathrm{H}, \mathrm{dd}, J=5.77, J=$ 5.68), $4.60(1 \mathrm{H}, \mathrm{dd}, J=8.30, \mathrm{~J}=8.79), 4.94-5.00(1 \mathrm{H}, \mathrm{m}) ;{ }^{13} \mathrm{C}$ NMR (400 MHz, $\left.\mathrm{CDCl}_{3}\right) \delta: 43.6,66.0,74.2,154.1$.

Large scale synthesis of 4-methyl-1,3-dioxolan-2-one (propylene carbonate) 5g. Propylene oxide $5 \mathrm{~g}(10 \mathrm{~g}, 170 \mathrm{mmol})$ in acetonitrile $(100 \mathrm{~mL})$ was added to a solution of supporting electrolyte: $\mathrm{Bu}_{4} \mathrm{NBr}(54.8 \mathrm{~g}, 170 \mathrm{mmol})$ in acetonitrile $(500 \mathrm{~mL})$, the resulting solution was flushed with $\mathrm{CO}_{2}$ (flow rate: $1000 \mathrm{~mL}$ $\min ^{-1}$ ) for $1 \mathrm{~h}$, followed by heated electrolysis at $50{ }^{\circ} \mathrm{C}$ and constant current: $60 \mathrm{~mA}$ with constant stirring for $10 \mathrm{~h}$ under $\mathrm{CO}_{2}$ balloon, in a single compartment cell containing a magnesium anode and copper cathode. On completion the reaction mixture was evaporated to dryness affording 4-methyl1,3-dioxolan-2-one $\mathbf{5 g}$ as a crude amber solid (conv: 100\%). The solid was partitioned between aqueous $0.1 \mathrm{M} \mathrm{HCl}(50 \mathrm{~mL})$ and $\mathrm{Et}_{2} \mathrm{O}$ and extracted. The combined organic extracts were then dried over $\mathrm{MgSO}_{4}$ and evaporated under reduced pressure to afford a amber oil, which was suspended in EtOAc $(100 \mathrm{~mL})$. After $1 \mathrm{~h}$ the precipitated $\mathrm{Bu}_{4} \mathrm{NBr}$ was removed by filtration and the solvent evaporated under reduced pressure to afford an amber oil. This crude material was purified by column chromatography on silica gel eluting with ethyl acetate:light petroleum. To afford the product as a colourless oil.

\section{Acknowledgements}

B.R.B. and K.G.U.W. would like to thank Research Councils UK for RCUK fellowships and Loughborough University for funding a PhD studentship (to A.P.P.).

\section{Notes and references}

1 R. J. Pearson, et al., Proc. IEEE, 2012, 100, 440.

2 Contribution of Working Group III to the Fourth Assessment Report of the Intergovernmental Panel on Climate Change, ed. B. Metz, O.R. Davidson, P.R. Bosch, R. Dave and L.A. Meyer, Cambridge University Press, United Kingdom and New York, NY, USA., 2007.

3 P. Styring, D. Jansen, H. de Coninck and K. Armstrong, Carbon Capture and Utilisation in the green economy, Report No. 501, The Centre For Low Carbon Futures, July 2011, ISBN 978-0-9572588-0-8.

4 M. North, R. Pasquale and C. Young, Green Chem., 2010, 12, 1514.

5 For some recent reviews and articles on high pressure and/or temperature approaches to cyclic carbonates see: (a) C. Maeda, Y. Miyazaki and T. Ema, Catal. Sci. Technol., 2014, 4, 1482; (b) N. Kielland, C. J. Whiteoak and A. W. Kleij, Adv. Synth. Catal., 2013, 355, 2115; (c) I. Omae, Coord. Chem. Rev., 2012, 256, 1384; (d) D. J. Darensbourg and S. J. Wilson, Green Chem., 2012, 14, 2665-2671; (e) S. Klaus, M. W. Lehenmeier, C. E. Anderson and B. Rieger, Coord. Chem. Rev., 2011, 255, 1460; (f) T. Sakakura and 
K. Kohno, Chem. Commun., 2009, 1312; (g) D. J. Darensbourg, Chem. Rev., 2007, 107, 2388.

6 (a) T. Ema, Y. Miyazaki, T. Taniguchi and J. Takada, Green Chem., 2013, 15, 2485; (b) T. Ema, Y. Miyazaki, S. Koyama, Y. Yano and T. Sakai, Chem. Commun., 2012, 48, 4489; (c) Z.-Z. Yang, Y.-N. Zhao, L.-N. He, J. Gao and Z.-S. Yin, Green Chem., 2012, 14, 519; (d) D. Bai, Q. Wang, Y. Song, B. Li and H. Jing, Catal. Commun., 2011, 12, 684; (e) F. Ahmadi, S. Tangestaninejad, M. Moghadam, V. Mirkhani, I. Mohammadpoor-Baltork and A. R. Khosropour, Inorg. Chem. Commun., 2011, 14, 1489; $(f)$ S. Liang, H. Liu, T. Jiang, J. Song, G. Yang and B. Han, Chem. Commun., 2011, 47, 2131; $(g)$ L. Han, H.-J. Choi, S.-J. Choi, B. Liu and D.-W. Park, Green Chem., 2011, 13, 1023; $(h)$ H. Zhou, Y.-M. Wang, W.-Z. Zhang, J.-P. Qu and X.-B. Lu, Green Chem., 2011, 13, 644; (i) Y. Tsutsumi, K. Yamakawa, M. Yoshida, T. Ema and T. Sakai, Org. Lett., 2010, 12, 5728; (j) M. Ulusoy, E. Çetinkaya and B. Çetinkaya, Appl. Organomet. Chem., 2009, 23, 68; (k) J. Song, Z. Zhang, S. Hu, T. Wu, T. Jiang and B. Han, Green Chem., 2009, 11, 1031.

7 (a) M. R. Kember and C. K. Williams, J. Am. Chem. Soc., 2012, 134, 15676; (b) A. Buchard, F. Jutz, M. R. Kember, A. J. White, H. S. Rzepa and C. K. Williams, Macromolecules, 2012, 45, 6781; (c) M. R. Kember, F. Jutz, A. Buchard, A. J. P. White and C. K. Williams, Chem. Sci., 2012, 3, 1245; (d) J. G. Kim, C. D. Cowman, A. M. LaPointe, U. Wiesner and G. W. Coates, Macromolecules, 2011, 44, 1110; (e) F. Jutz, A. Buchard, M. R. Kember, S. B. Fredriksen and C. K. Williams, J. Am. Chem. Soc., 2011, 133, 17395; (f) G.-P. Wu, S.-H. Wei, W.-M. Ren, X.-B. Lu, T.-Q. Xu and D. J. Darensbourg, J. Am. Chem. Soc., 2011, 133, 15191; $(g)$ H. Li and Y. Niu, Appl. Organomet. Chem., 2011, 25, 424; $(h)$ K. Nakano, K. Kobayashi and K. Nozaki, J. Am. Chem. Soc., 2011, 133, 10720; (i) A. Buchard, M. R. Kember, K. G. Sandeman and C. K. Williams, Chem. Commun., 2010, 47, 212; (j) M. R. Kember, A. Buchard and C. K. Williams, Chem. Commun., 2010, 47, 141; (k) K. Nakano, S. Hashimoto and K. Nozaki, Chem. Sci., 2010, 1, 369; $(l)$ D. J. Darensbourg, Inorg. Chem., 2010, 49, 10765; $(\mathrm{m})$ J. Yoo, S. J. Na, H. C. Park, A. Cyriac and B. Y. Lee, Dalton Trans., 2010, 2622; (n) S. I. Vagin, R. Reichardt, S. Klaus and B. Rieger, J. Am. Chem. Soc., 2010, 132, 14367; (o) M. R. Kember, A. J. P. White and C. K. Williams, Inorg. Chem., 2009, 48, 9535; (p) M. R. Kember, P. D. Knight, P. T. R. Reung and C. K. Williams, Angew. Chem., Int. Ed., 2009, 48, 931; (q) K. Nakano, M. Nakamura and K. Nozaki, Macromolecules, 2009, 42, 6972.
8 (a) M. North, B. Wang and C. Young, Energy Environ. Sci., 2011, 4, 4163; (b) M. North and C. Young, Catal. Sci. Technol., 2011, 1, 93; (c) W. Clegg, R. W. Harrington, M. North and P. Villuendas, J. Org. Chem., 2010, 75, 6201; (d) W. Clegg, R. W. Harrington, M. North, F. Pizzato and P. Villuendas, Tetrahedron: Asymmetry, 2010, 21, 1262; (e) W. Clegg, R. W. Harrington, M. North and R. Pasquale, Chem.-Eur. J., 2010, 16, 6828; (f) I. S. Metcalfe, M. North, R. Pasquale and A. Thursfield, Energy Environ. Sci., 2010, 3, 212; $(g)$ M. North, P. Villuendas and C. Young, Chem.-Eur. J., 2009, 15, 11454; (h) M. North, Angew. Chem., Int. Ed., 2009, 48, 4104; (i) M. North and R. Pasquale, Angew. Chem., Int. Ed., 2009, 48, 2946; (j) J. Meléndez, M. North and P. Villuendas, Chem. Commun., 2009, 2577; ( $k$ ) J. Meléndez, M. North and R. Pasquale, Eur. J. Inorg. Chem., 2007, 3323.

9 (a) F. Castro-Gómez, G. Salassa, A. W. Kleij and C. Bo, Chem.Eur. J., 2013, 19, 6289; (b) C. J. Whiteoak, N. Kielland, V. Laserna, E. C. Escudero-Adán, E. Martin and A. W. Kleij, J. Am. Chem. Soc., 2013, 135, 1288; (c) C. J. Whiteoak and A. W. Kleij, Synlett, 2013, 1748; (d) C. J. Whiteoak, E. Martin, M. M. Belmonte, J. Benet-Buchholz and A. W. Kleij, Adv. Synth. Catal., 2012, 354, 469; (e) A. Coletti, C. J. Whiteoak, V. Conte and A. W. Kleij, ChemCatChem, 2012, 4, 1190.

10 (a) P. Tascedda and E. Duñach, J. Chem. Soc., Chem. Commun., 1995, 43-44; (b) E. Duñach, P. Tascedda, M. Weidmann and E. Dinjus, Appl. Organomet. Chem., 2001, 15, 141.

11 (a) B. R. Buckley, A. P. Patel and K. G. U. Wijayantha, Chem. Commun., 2011, 47, 11888; (b) B. R. Buckley, Y. Chan, N. Dreyfus, C. Elliott, F. Marken and P. C. B. Page, Green Chem., 2012, 14, 2221; (c) P. C. B. Page, F. Marken, C. Williamson, Y. Chan, B. R. Buckley and D. Bethell, Adv. Synth. Catal., 2008, 350, 1149.

12 (a) A. A. Tahir and K. G. U. Wijayantha, J. Photochem. Photobiol., A, 2010, 216, 119; (b) A. A. Tahir, K. G. U. Wijayantha, S. Saremi-Yarahmadi, M. Mazhar and V. McKee, Mater. Chem., 2009, 21, 3763; (c) K. Tennakone, G. R. R. A. Kumara, K. G. U. Wijayantha, I. R. M. Kottegoda, V. P. S. Perera and M. L. P. Aponsu, J. Photochem. Photobiol., A, 1997, 108, 175.

13 E. Dunach and J. Perichon, J. Organomet. Chem., 1988, 352, 239.

14 (a) A. V. Getsis and Z. Mudring, Anorg. Allg. Chem., 2008, 634, 2130; (b) A. V. Getsis and Z. Mudring, Anorg. Allg. Chem., 2008, 634, 619.

15 E. Styczen, W. K. Jozwiak, M. Gazda and D. Wyrzykowski, J. Therm. Anal. Calorim., 2008, 91, 979. 